\title{
A case of postmenopausal bleeding with an unusual finding
}

\author{
Samar Rudra, Manasi Thakur*
}

\begin{abstract}
Department of Obstetrics and Gynecology, Dr. D. Y. Patil Medical College and Hospital, Dr. D. Y. Patil Vidyapeeth,
\end{abstract} Pimpri, Pune, Maharashtra, India

Received: 10 December 2019

Accepted: 04 January 2020

\section{*Correspondence:}

Dr. Manasi Thakur,

E-mail: manasi18393@gmail.com

Copyright: () the author(s), publisher and licensee Medip Academy. This is an open-access article distributed under the terms of the Creative Commons Attribution Non-Commercial License, which permits unrestricted non-commercial use, distribution, and reproduction in any medium, provided the original work is properly cited.

\begin{abstract}
Authors report the case of a 55-year-old patient who presented with postmenopausal bleeding. On clinical evaluation uterus was 12 weeks size with a left sided adnexal cystic mass of $8 \times 6 \mathrm{~cm}$ size. Further imaging studies revealed uterus size of $11.5 \times 6.7 \times 6.3 \mathrm{~cm}$, left ovarian mass of size $8.4 \times 6.7 \times 6 \mathrm{~cm}$ and endometrial thickness of $17 \mathrm{~mm}$ on ultrasonography. She underwent endometrial biopsy to exclude endometrial cancer. The report of which came to be endometrial hyperplasia without atypia. Further MRI study confirmed the findings of USG of a complex cystic lesion of left adnexa $75 \times 57 \times 60 \mathrm{~mm}$. Tumor marker for ovarian tumors were sent and inhibin B was found to be markedly raised. A provisional diagnosis of GCT (Granulosa cell tumour) was made and staging laparotomy was done. The uterus was found to be $12 \times 8 \mathrm{~cm}$ size and a left sided ovarian cyst of $8-9 \mathrm{~cm}$ size with smooth wall and intact capsule was found. Patient had an uneventful postoperative recovery.
\end{abstract}

Keywords: Adnexal mass, Endometrial hyperplasia, Granulosacell tumour, Inhibin B, Ovarian tumour, Postmenopausal bleeding

\section{INTRODUCTION}

The irregular proliferation of endometrial glands is referred as endometrial hyperplasia $(\mathrm{EH})$. Increase in the endometrial gland to stroma ratio is a characteristic feature and distinguish $\mathrm{EH}$ from the proliferative endometrium. The estimated incidence of $\mathrm{EH}$ is 133 per 100,000 -woman years and is highest among women aged 50-54. ${ }^{1}$ In the majority of cases, the causative factor for this pathology is chronic estrogen stimulation unopposed by progestin action.

Rarely, the source of excessive estrogen stimulation is an ovarian tumor. Such EH can cause postmenopausal bleeding. In patients with granulosa cell tumors, estrogendependent endometrial cancers can be found, and most of them are well-differentiated endometrioid adenocarcinomas that carry a good prognosis when detected early. ${ }^{2}$ However proper history, physical examination and appropriate investigations are essential to establish a definite diagnosis.

\section{CASE REPORT}

A 55-year-old female, homemaker, menopausal since $2 \frac{1}{2}$ years presented with complaints of postmenopausal bleeding since 1 month. The bleeding was associated with passage of clots but no dysmenorrhea. She also had a history of minimal white discharge per vaginum since 1 month.

There was no history of postcoital bleeding or dyspareunia. Her previous menstrual cycles were regular and there was no history of passage of clots or dysmenorrhea. She was a third para with all normal deliveries. There were no associated bladder or bowel complaints. There was no other significant illness in the past or similar history in her family 


\section{Physical findings}

On examination her vital parameters were normal. There was no pallor or icterus. Bilateral breasts were normal. Abdomen was soft and non-tender. There was no clinical evidence of ascites. On per speculum examination cervix and vagina were healthy. On per vaginal examination it was found that uterus was around 10 to 12 weeks size and deviated to the right side. A mass of $8 \times 8 \mathrm{~cm}$ was felt in left fornix pushing the uterus to the opposite side. Mass was firm to cystic in consistency, mobile and with a smooth surface. No other pathology detected in the pelvis clinically.

Routine haematological and biochemical parameters were within normal limits. Ultrasound of abdomen revealed uterus size of $11.5 \times 6.7 \times 6.3 \mathrm{~cm}$, endometrial thickness of $17 \mathrm{~mm}$, right ovary normal, left adnexa showed evidence of well-defined solid cystic lesion arising from the left ovary measuring approximately $8.4 \times 6.7 \times 6 \mathrm{~cm}$ with solid components showing internal vascularity on colour doppler suggestive of neoplastic etiology.

In view of a postmenopausal lady having endometrial thickness of $17 \mathrm{~mm}$ and bulky uterus, an endometrial biopsy was done to find any malignancy of endometrium. However, the HPE report came out to be as endometrial hyperplasia without atypia.

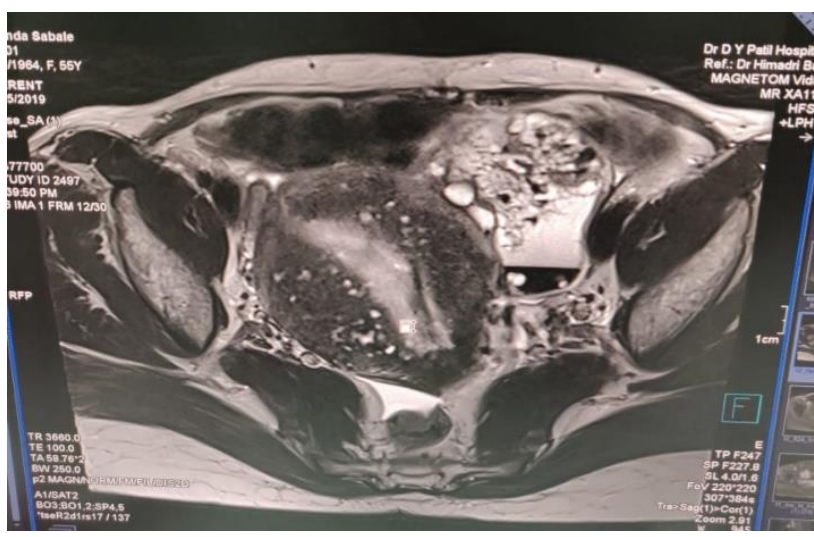

Figure 1: MRI pelvis showing enlarged uterus with thickened endometrium and left sided complex adnexal mass.

Considering her history, examination finding, ultrasound and endometrial biopsy reports, a hormone producing tumour was suspected. Hence tumor markers for ovarian tumour like CA-125, $\beta$ hCG and inhibin B were sent. Tumour markers other than inhibin were in normal range. Inhibin B was found to be highly significant with a value of >1300, supporting our diagnosis of a hormone producing tumour commonest being granulosa cell tumor. In order to know the extent of the disease a contrast MRI of abdomen and pelvis was done (Figure 1) which reported as complex cystic lesion of $75 \times 57 \times 60$ $\mathrm{mm}$ seen in left adnexa showing multiple septa and small cysts within. Blood fluid levels were seen within the cysts. On contrast study, lesion showed peripheral wall as well as septal enhancement. No obvious solid nodule noted. Left ovary was not seen separately from the lesion. Uterus was bulky, measuring $110 \times 61 \times 67 \mathrm{~mm}$ with thickening of end myometrial junctional zone with multiple small cysts within. Lower thoracic sections showed bilateral minimal pleural effusion, no other lung pathology seen on MRI.

A final diagnosis of hormone producing tumour was made and patient was taken up for staging laparotomy after getting all pre-operative workup done and with due consent of the patient.

On opening the abdomen around $200 \mathrm{ml}$ of ascitic fluid was found in the POD. It was sent for cytology. Uterus was around 12 weeks size. Left sided ovarian tumor of around $8 \times 7 \mathrm{~cm}$ was seen with smooth surface and intact capsule. Other ovary and tubes were normal. There were no peritoneal deposits. POD and paracolic gutters were free of deposits. There were no omental deposits. Staging laparotomy was done.

Gross specimen of uterus which was about $12 \times 8 \mathrm{~cm}$ in size. Cut surface showed thick endometrium with myohyperplasia. The left sided ovarian tumour was 9-8 $\mathrm{cm}$ size with cystic and solid component (Figure 2).

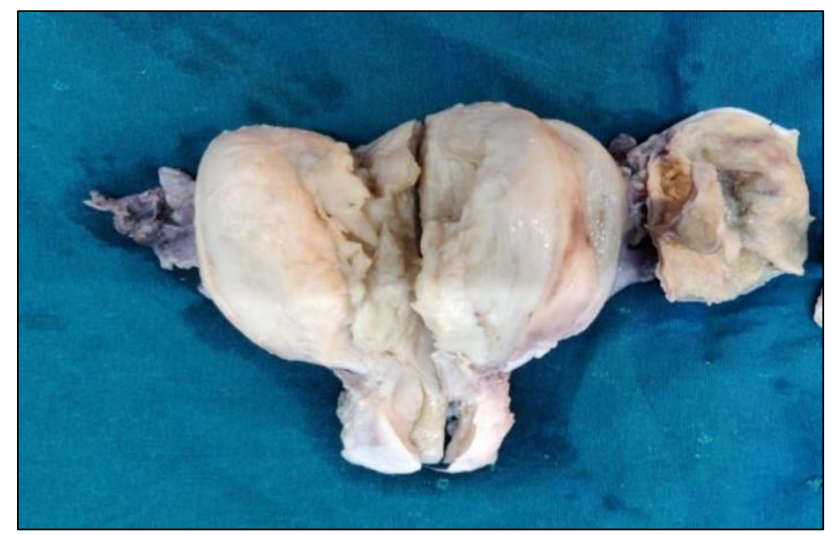

Figure 2: Gross specimen of uterus with endometrial hyperplasia and left sided ovarian tumour.

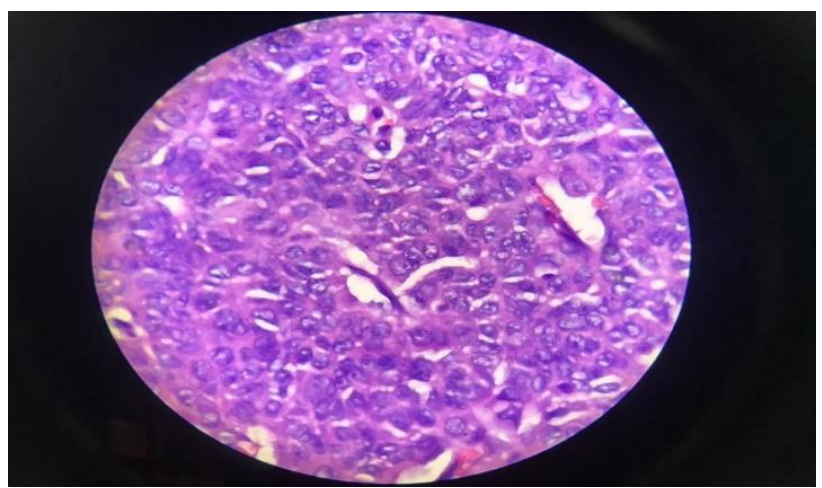

Figure 3: Tumor cells showing coffee bean nucleus in high power microscopy. 
The peritoneal fluid cytology report came as negative for malignancy.

Histopathology picture of left ovary showed features of granulosa cell tumour such as some cells showing grooved nuclei (coffee bean nucleus) and call exner bodies. Uterine tissue was showing adenomyosis (Figure $3)$.

Thus, the final diagnosis of granulosa cell tumor of the left ovary stage I A is made. Patient went home on $8^{\text {th }}$ postoperative day after removal of stitches, with an advice to come for regular follow-up.

\section{DISCUSSION}

Granulosa cell tumors are the most common type of malignant ovarian sex cord-stromal tumor and make up $2 \%$ to $5 \%$ of all ovarian malignancies. They account for $70 \%$ of ovarian sex cord-stromal tumors. Granulosa cell tumors are considered to be low-grade malignancy. Adult granulosa cell tumors (AGCT) $(95 \%)$ almost always occur in postmenopausal women while juvenile granulosa cell tumors $(5 \%)$ are diagnosed in women under 30 years of age and may be seen in prepubertal girls in $5 \%$ of cases. $^{3}$

Common symptoms in the adult granulosa cell tumors are postmenopausal bleeding, menstrual irregularities or secondary amenorrhea and frequently cystic hyperplasia of the endometrium. One of rare symptom or way of presentation of GCTs could be delayed menopause. ${ }^{4}$ Other signs and symptoms are similar to most ovarian malignancies. Ascites is present in $10 \%$ of cases and rarely a pleural effusion is present as seen in our case. Granulosa cell tumors tend to be hemorrhagic; occasionally, they may rupture and produce a hemoperitoneum. ${ }^{5}$

About $70 \%$ of granulosa cell tumors secrete estrogen or androgens. Inhibin is secreted by some adult granulosa cell tumors and is a useful marker for the disease.,7 Inhibin is a peptide hormone that is produced by granulosa cells and plays a role in regulation of FSH secretion. Inhibin exists in two different isoforms: inhibin A and inhibin B. Serum levels of inhibin B are more frequently elevated. ${ }^{8}$ Inhibin levels can be used to monitor patients during follow-up or to assess response to treatment. Seventy-five percent of women with AGCT's also have an elevated anti-müllerian hormone preoperatively and $\mathrm{AMH}$ has a > 90\% sensitivity in detecting recurrence.

Low-grade endometrial cancer occurs in association with adult granulosa cell tumors in at least $5 \%$ of cases, and $25 \%$ to $50 \%$ are associated with endometrial hyperplasia which was seen in this case. ${ }^{9}$ In patients with granulosa cell tumors, estrogen dependent endometrial cancers can be found, and most of them are well-differentiated endometrioid adenocarcinomas that carry a good prognosis when detected early. ${ }^{10}$ Adult granulosa cell tumors are stage I at diagnosis in $90 \%$ of patients and are associated with a very good prognosis. Our case was also a stage I disease. However, it may recur in 5 to 30 years after initial diagnosis. ${ }^{11}$

The treatment of granulosa cell tumors depends on the age of the patient and the extent of disease. For most patients, surgery alone is sufficient primary therapy; radiation and chemotherapy are reserved for the treatment of recurrent or metastatic disease. ${ }^{12}$

A unilateral salpingo-oophorectomy is appropriate therapy for stage IA tumors in children or in women of reproductive age who desire to preserve their fertility. As uterus is left in situ in these cases an endometrial biopsy should be performed to rule out the possibility of a coexistent adenocarcinoma of the endometrium. For perimenopausal and postmenopausal women for whom ovarian preservation is not important, a hysterectomy and bilateral salpingo-oophorectomy should be performed. ${ }^{3}$

Role of radiotherapy and chemotherapy is limited in these tumours. There is no evidence to support the use of adjuvant radiation therapy for granulosa cell tumors, although pelvic irradiation may help to palliate isolated pelvic recurrences. ${ }^{13}$ Adjuvant chemotherapy has been used for advanced disease and for recurrence. Granulosa cell tumors are potentially hormonally responsive, with about $30 \%$ of granulosa tumors expressing estrogen receptors and almost $100 \%$ expressing progesterone receptors. Hormonal agents such as progestins or luteinizing hormone-releasing hormone agonists or aromatase inhibitors have been used to treat these patients. ${ }^{14,15}$

Adult granulosa cell tumors have a prolonged natural history and a tendency toward late relapse, reflecting their low-grade biology. Ten-year survival rates of about $90 \%$ are reported, with 20 -year survival rates dropping to $75 \% .{ }^{16}$ The DNA ploidy of the tumors is correlated with survival.

\section{CONCLUSION}

Various etiologies of postmenopausal bleeding should be kept in mind for proper diagnosis and management of the case. Granulosa cell tumour should always be kept in mind as a differential diagnosis of postmenopausal bleeding associated with adenexal mass. In our case, we kept the suspicion of granulosa cell tumour from the very first day when the patient presented in the OPD, from her symptoms and clinical findings. The case is presented to make the clinician aware of the possibilities of a hormone producing tumour in a patient presenting with postmenopausal bleeding.

Funding: No funding sources

Conflict of interest: None declared

Ethical approval: Not required 


\section{REFERENCES}

1. Reed SD, Newton KM, Clinton WL, Epplein M, Garcia R, Allison K, et al. Incidence of endometrial hyperplasia. Am J Obstet Gynecol. 2009;200:678.e16.

2. Gruber SB, Thompson WD. A population-based study of endometrial cancer and familial risk in younger women. Cancer and Steroid Hormone Study Group. Cancer Epidemiol Biomarkers Prev. 1996;5:411-7.

3. Segal R, DePetrillo AD, Thomas G. Clinical review of adult granulosa cell tumors of the ovary. Gynecol Oncol. 1995;56:338-44.

4. Vyas MN, Manjeera L, Rai S. Delayed menopause due to ovarian granulosa cell tumour. J Clin Diag Res. 2013;7(10):2306-7.

5. Miller BE, Barron BA, Wan JY, Delmore JE, Silva EG, Gershenson DM, et al. Prognostic factors in adult granulosa cell tumor of the ovary. Cancer. 1997;79:1951-5.

6. Lappohn RE, Burger HG, Bouma J. Inhibin as a marker for granulosa-cell tumors. $\mathrm{N}$ Engl $\mathrm{J}$ Med. 1989;321:790-3.

7. Hildebrandt RH, Rouse RV, Longacre TA. Value of inhibin in the identification of granulosa cell tumors of the ovary. Hum Pathol. 1997;28:1387-95.

8. Mom CH, Engelen MJ, Willemse PH, Gietema JA, Ten Hoor KA, de Vries EG, et al. Granulosa cell tumors of the ovary: The clinical value of serum inhibin A and B levels in a large single center cohort. Gynecol Oncol. 2007;105(2):365-72.

9. Scully RE, Young RH, Clement PB. Tumors of the ovary, maldeveloped gonads, fallopian tube, and broad ligament. In: Atlas of Tumor Pathology.
Washington, DC: Armed Forces Institute of Pathology; 1998;23:3rd series.

10. Ukah CO, Ikpeze OC, Eleje GU, Eke AC. Adult granulosa cell tumor associated with endometrial carcinoma: a case report. J Med Case Reports. 2011;5:340.

11. Malmström H, Högberg T, Risberg B, Simonsen E. Granulosa cell tumors of the ovary: Prognostic factors and outcome. Gynecol Oncol. 1994;52:50-5.

12. Shah SP, Köbel M, Senz J. Mutation of FOXL2 in granulosa-cell Tumors of the ovary. N Engl J Med. 2009;360:2719-29.

13. Wolf JK, Mullen J, Eifel PJ, Burke TW, Levenback C, Gershenson DM. Radiation treatment of advanced or recurrent granulosa cell tumor of the ovary. Gynecol Oncol. 1999;73:35-41.

14. Hardy RD, Bell JG, Nicely CJ, Reid GC. Hormonal treatment of a recurrent granulosa cell tumor of the ovary: Case report and review of the literature. Gynecol Oncol. 2005;96:865-9.

15. Korach J, Perri T, Beiner M, Davidzon T, Fridman E, Ben-Baruch G. Promising effect of aromatase inhibitors on recurrent granulosa cell tumors. Int J Gynecol Cancer. 2009;19:830-3.

16. Rey RA, Lhomme C, Marcillac I, Lahlou N, Duvillard P, Josso N, Bidart JM. Antimullerian hormone as a serum marker of granulosa cell tumors of the ovary: comparative study with serum alphainhibin and estradiol. Am J Obstet Gynecol. 1996;174:958-65.

Cite this article as: Rudra S, Thakur M. A case of postmenopausal bleeding with an unusual finding. Int J Reprod Contracept Obstet Gynecol 2020;9:835-8. 